\title{
Level of Understanding of The Health Protocol Slaughtering Qurban Animal During COVID 19 Pandemic in West Kotawaringin District
}

\author{
Ayutha Wijinindyah ${ }^{1}$, and Ida Ketut Mudhita ${ }^{2}$ \\ 1,2Program Study of Animal Husbandry, Agriculture Faculty, Universitas Antakusuma \\ Jalan Iskandar No. 63 Pangkalan Bun Kalimantan Tengah \\ Corresponding author : aaayutha@gmail.com
}

\begin{abstract}
Slaughtering of animal qurban was a form of worship Muslim. In the current pandemic situation, it is necessary to pay attention to the procedure of slaughtering animal qurban so that their implementation is in accordance with health protocols. This was to make the slaughter of animal qurban in accordance with Islamic law and minimize the pread of covid 19. The data analysis technique in this study was descriptive quantitative with purposive sampling and the analyzed using research instruments. The result show that the public already understands the health protocol for slaughtering animal qurban during pandemic in new normal. This can been that $92 \%$ of the understanding of the slaughter animals is very good. In conclusion, offices generally know health protocol and are able to apply them to sacritificial animal slaughtering activities.
\end{abstract}

Keywords : slaughter, qurban animal, pandemic, new normal, health public

\section{Introduction}

Islam is the majority religion in Indonesia. The total population of Indonesia until 2019 is estimated to be $87.2 \%$ (207.2 million) of the population adheres to Islam. Even at the world level, several media claim that the number of adherents of Islam in Indonesia is the largest in the world (Syafii, 2019). One of the Muslim holidays is Eid al-Adha or known as the Feast of Sacrifice, which aims to get closer to Allah SWT (Jayusman, 2012). Qurban worship in Islam is a form of devotion to Allah SWT which is a manifestation of faith, namely gratitude for the blessings that exist (Sabiq, 1983), but the organization of Qurban this year is different due to the Covid-19 outbreak, so it is necessary to carry out the handling of the slaughter of sacrificial animals with The Health protocol of the Indonesian Ulema Council (MUI) provides guidance in community activities, especially when slaughtering sacrificial animals. This is as stated in the MUI fatwa Number 36 of 2020 concerning the application of health protocols when slaughtering sacrificial animals.

Coronavirus disease or Covid-19 is an infectious disease caused by the acute respiratory syndrome Coronavirus 2 (Sars-CoV-2) with common symptoms including fever, cough, and shortness of breath. Cases in Indonesia are the highest mortality rate in Asia Pacific and Southeast Asia (Tribunnewsmaker, 2020). The World Health Organization (WHO) has declared a global pandemic status of Covid-19. Mass gatherings in large numbers have been avoided to avoid the transmission process. Covid-19 is widely present in animals as hosts (Su et al., 2019; Cui et al., 2019), so it is very important to maintain the health of livestock, because it is one of the issues in animal husbandry (Decaro and Lorusso , 2020). In fact, this has an impact on the PSBB adjustment during the pandemic (Muhyiddin, 2020). 
The implementation of health protocols is an effort to overcome Covid-19. Things that need to be considered because of physical distancing and the application of sanitation hygiene because the transmission of the virus is very easy to move. In fact, the Eid alAdha activity will gather several people at the time of slaughtering sacrificial animals, sorting and distributing them. Everyone has the potential to infect, so maintaining activity procedures with health protocols will protect everyone involved during activities, supply chains and critical points that have the potential to spread the virus (WHO, 2020). The slaughter of sacrificial animals has caused many polemics related to the Covid-19 pandemic. Based on the above background, a study was conducted with the aim of knowing the understanding of health protocols for slaughtering sacrificial animals in the new normal era in West Kotawaringin Regency, Central Kalimantan.

\section{Materials and Methods}

This research was conducted in July 2021, during the two-day Eid al-Adha holiday at 13 cutting locations (mosques and non-mosques) in the Pangkalan Bun area, West Kotawaringin Regency, Central Kalimantan.

Research equipment uses questionnaires to obtain primary data and other supporting equipment.

The research method used is a survey method, with purposive sampling in West Kotawaringin Regency, namely at several points where sacrificial animals are slaughtered. A total of 13 samples were obtained in this study, because during the PPKM (Enforcement of Community Activity Restrictions), not all people carried out slaughtering Qurban animals. Methods of collecting data by observation and interviews using a questionnaire to obtain data about the level of understanding of the health protocol of slaughtering officers.

The data obtained were analyzed using excel with measurement methods to determine public understanding of the protocol for slaughtering sacrificial animals during the PPKM period using the Guttman and SPSS formulas.

\section{Result and Discussion}

The results of the study on the understanding of health protocols by slaughterhouse officers during Eid al-Adha in the Covid-19 pandemic situation, are presented in Table 1.

Table 1. Understanding of Health Protocols on Sacrificial Animal Slaughter in the New Normal Era in Kotawaringin Barat Regency.

\begin{tabular}{cccccccc}
\hline No & \multicolumn{1}{c}{ Question } & Yes & No & Mean & Median & Mode & Std. \\
\hline 1 & & & & & & \\
$\begin{array}{l}\text { Slaughter of sacrificial animals is carried out } \\
\text { at a facility for slaughtering sacrificial } \\
\text { animals that has received permission from } \\
\text { the local district or city government in charge } \\
\text { of veterinary public health functions. }\end{array}$ & $69,23 \%$ & $30,77 \%$ & .69 & 1.00 & 1 & .480 \\
2 & & & & & & & \\
$\begin{array}{l}\text { The committee also comes from the same } \\
\text { neighborhood and is not in self-quarantine } \\
\text { Taking body temperature measurements at } \\
\text { each entrance to the slaughterhouse }\end{array}$ & $100,00 \%$ & $0,00 \%$ & .77 & 1.00 & 1 & .439 \\
3 & $15,38 \%$ & $84,62 \%$ & .77 & 1.00 & 1 & .439
\end{tabular}


4 Everyone who has symptoms of fever or sore throat or cough, runny nose or shortness of breath, is prohibited from entering the slaughterhouse

5 There are officers in the area of slaughter and handling of meat and offal

6 There is education from the officer in charge of sacrificial activities, namely educating everyone to avoid or touch the face (including eyes, nose, ears and mouth).

7 Everyone wears protective gear

8 Officers wear masks, face shields, disposable gloves, aprons, and foot or shoe covers (choose one)

9 The person in charge of sacrificial activities provides hand washing facilities using soap or hand sanitizer facilities

10 Everyone avoid shaking hands or direct contact and pay attention to the etiquette of coughing, sneezing and spitting

11 Officers bring their own equipment or do not borrow tools from each other

12 There is a procedure to regulate the density by limiting the number of committees in carrying out the slaughter of sacrificial animals

13 There is a restriction treatment at the sacrificial animal slaughter facility which is only attended by the committee

14 There is a minimum distance setting of 1 meter

15 Do not face each other between officers when carrying out activities of skinning, chopping, handling and packaging meat

16 Everyone cleans the slaughterhouse and equipment that will or has been used and disposes of dirt or waste at the sewage or waste handling facility

17 Everyone at the slaughterhouse cleans up before making contact with family at home

18 The distribution of the sacrificial meat is carried out by the committee to the mustahik's house

19 Officers know the slaughtering protocol in the new normal era

$\begin{array}{llllll}61,54 \% & 38,46 \% & 1.00 & 1.00 & 1 & .000\end{array}$

$\begin{array}{llllll}92,31 \% & 7,69 \% & .62 & 1.00 & 1 & .506\end{array}$

$\begin{array}{llllll}100,00 \% & 0,00 \% & .92 & 1.00 & 1 & .277\end{array}$

$\begin{array}{llllll}100,00 \% & 0,00 \% & .77 & 1.00 & 1 & .439\end{array}$

$\begin{array}{llllll}92,31 \% & 7,69 \% & 1.00 & 1.00 & 1 & .000\end{array}$

$\begin{array}{llll}1.00 & 1.00 & 1 & .000\end{array}$

$76,92 \% \quad 23,08 \%$

$76,92 \% \quad 23,08 \%$

$\begin{array}{llll}1.00 & 1.00 & 1 & .000\end{array}$

$\begin{array}{llllll}69,23 \% & 30,77 \% & .85 & 1.00 & 1 & .376\end{array}$

$\begin{array}{lllll} & .15 & .00 & 0 & .376\end{array}$

$76,92 \% \quad 23,08 \%$

$\begin{array}{lll}1.00 \quad & 1 & .277\end{array}$

$100,00 \% \quad 0,00 \% \quad .92$

$84,62 \% \quad 15,38 \%$

$\begin{array}{llll}1.00 & 1.00 & 1 & .000\end{array}$

$\begin{array}{llllll}84,62 \% & 15,38 \% & .85 & 1.00 & 1 & .376\end{array}$

20 Officers have received education or counseling from the service regarding the procedures for slaughtering sacrificial animals in the new normal era

$84,62 \% \quad 15,38 \%$

$\begin{array}{llll}.85 & 1.00 \quad 1 & .376\end{array}$

Source: processed primary data (2021) 


\section{Licensing}

People who use permits to slaughter cattle during Eid al-Adha during the Covid 19 pandemic in West Kotawaringin Regency are presented in Figure 1.

\section{Sacrificial Animal Slaughter License}

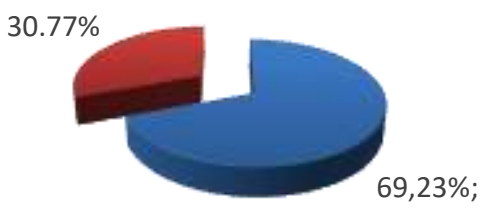

- Ya Tidak

Picture 1. Animal Slaughter License

The results showed that not all slaughtering locations had permits from the Livestock Service Office of West Kotawaringi Regency, only $69.23 \%$ of sacrificial animal slaughter was carried out after obtaining permission from the local government, and the remaining 30, 77\% did not apply for a permit. The slaughter of the Qurban animal should be carried out with the government's permission. The Ministry of Agriculture suggested that the Qurban committee apply for a permit to the local government if the slaughter is carried out outside the slaughterhouse (RPH). The best option for slaughter in the midst of a pandemic is to slaughter sacrificial animals at slaughterhouses (RPHs), especially those in the Covid-19 red zone, but if it is not possible then the implementation of the Qurban can be done independently, namely the Qurban committee must apply for a permit to the local government. The team from the Animal Husbandry Service will examine the sacrificial animal, namely the condition of the sacrificial animal as evidenced by an animal health certificate.

A total of $100 \%$ of the slaughter locations stated that the committee involved in the sacrificial animal slaughtering activity came from the same residential environment as the slaughter location, and it was confirmed that they were not currently in self-quarantine.

This is because there is a potential for food transmission due to workers, and the agricultural and livestock sectors are sources of contamination for food or contact on surfaces (Randazzo et al., 2020; Mukharom, 2020).

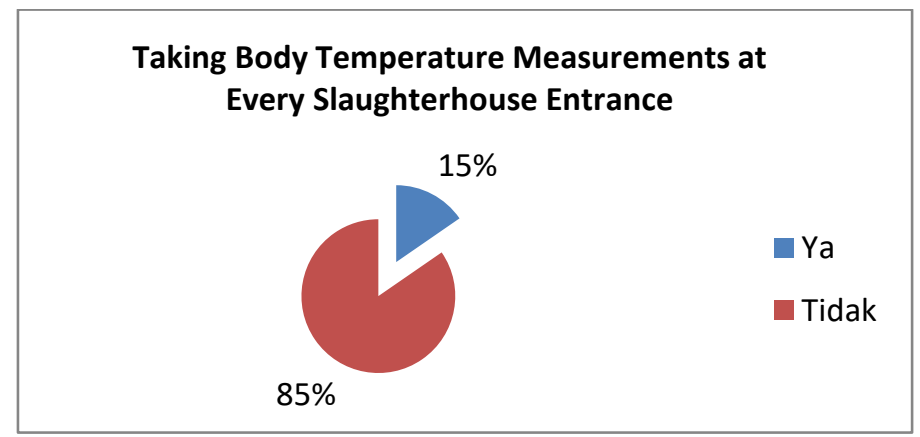


In the study, it was seen that there were still few places for slaughtering sacrificial animals that checked body temperature before the officers started their activities, which was only $15.38 \%$ taking body temperature measurements at each entrance to the slaughterhouse. This is due to the high cost of purchasing a body temperature screening tool, so many slaughterhouses do not provide such a device. Screening procedures, such as checking body temperature, are one of the initial measures to prevent the transmission of Covid-19 to others. (Dyal et al., 2020). Checking body temperature is an early indication, because one of the symptoms of being infected with Covid-19 is the presence of fever symptoms, which means an increase in body temperature. Alternatively, officers can independently monitor the characteristics of COVID symptoms (92.31\%), such as symptoms of fever, sore throat, cough, runny nose, or shortness of breath, so they are prohibited from entering the slaughterhouse.

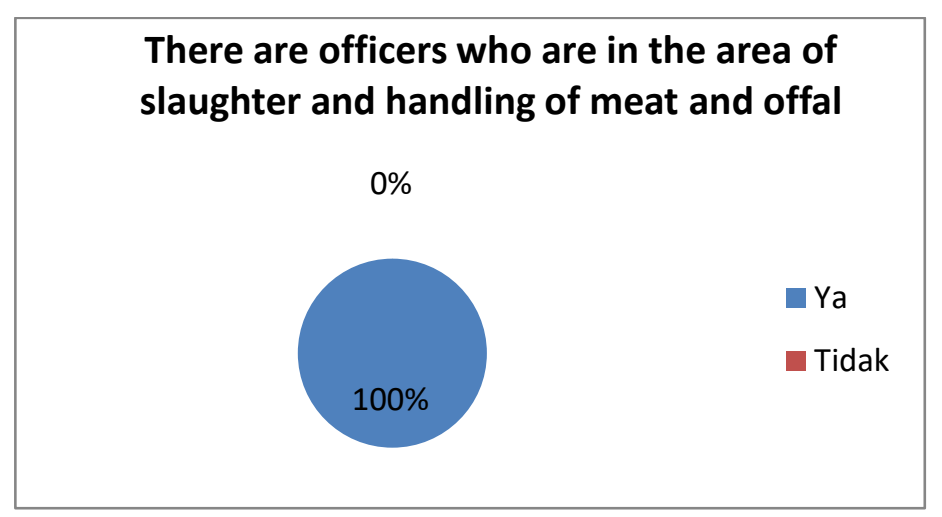

In the handling of sacrificial animals, $100 \%$ of the tasks have been divided between the slaughter area and the meat and offal handling area. As is well known that Covid-19 is zoonic, which means it can be transmitted from animals to humans. This can happen if infected animals are slaughtered for consumption (Chhikava et al., 2020; Yuan et al., 2020). Corona viruses have been identified to be found in bats, farm animals, rats, chickens, turkeys, pigs, dogs, rabbits, horses, and can cause respiratory and gastric disorders (Dhama et al., 2019; Monchatre et al., 2017; Pradesh et al., 2014; Rodrigeuez et al., 2020. Although research has not identified a relationship between food products and SARS-CoV-2, according to the FDA, consumption of meat or internal organs of animals can cause zoonotic foodborne infections ( Ehoffnes, 2020; Jenebit, 2019; Su and $\mathrm{Wu}, 2019$; Yuan et al., 2020).In the protocol for slaughtering sacrificial animals, it is important that there is a division of staff between the slaughter area and the handling of meat and offal, not in the same area with the same staff. (European Commission, 2020) Furthermore, the spread of SARS-CoV-2 from human to human was caused by unhygienic conditions during the slaughter process (Rodrigeuez et al., 2020)

The results showed that $61.54 \%$ of officers used protective equipment, including masks, face shields, disposable gloves, foot covers (shoes) $(92.31 \%)$. The protective equipment used was masks. Masks tend to be easy to obtain and the purchase cost is relatively affordable. 


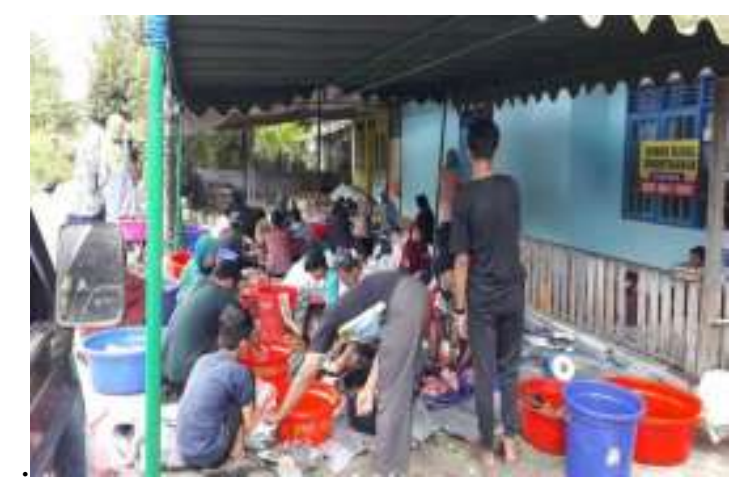

The stages of hygiene include spraying disinfectants on facilities and equipment, maintaining direct contamination between food ingredients, applying personal hygiene (such as washing hands with soap or using disinfectants, eating gloves, masks, face covers, paying attention to the cleanliness of clothes and shoes). The educational process in it also involves protocols that everyone avoid direct contact, pay attention to coughing, sneezing and spitting etiquette (100\%). This includes part of eliminating unhygienic habits such as sneezing and coughing everywhere (Government of Ireland, 2020; IACP, 2020, Wei et al., 2020).

The use of alcohol-based hand sanitizers is highly recommended by the Department of Agriculture for food safety in the United States, because it is possible that transmission of Covis-19 may occur due to the processing of meat and poultry that occurs in physical contact with officers (Dylah et al., 2020). This can be seen from the results that $100 \%$ of the people in charge of Qurban activities provide hand washing facilities using soap or hand sanitiser facilities. In the slaughter of Qurban, as many as $76.92 \%$ there are procedures to regulate the density by limiting the number of committees in the implementation of animal slaughter and the same value as limiting the facilities for slaughtering Qurban animals which are only attended by the committee.

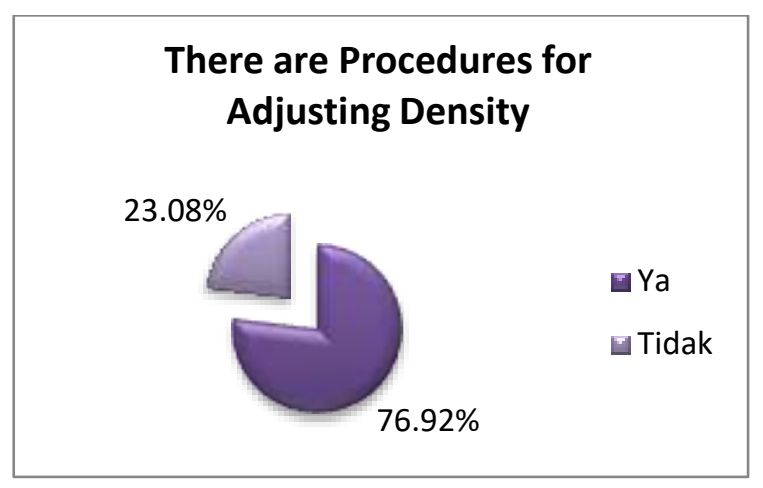

One important thing is to limit the number of people present or officers in the sacrificial animal slaughtering activity, including the Qurban committee, animal health inspectors or the owner of the Qurban animal. There are many ways that can be done, including limiting the number of Qurban committees to avoid physical contact and the spread of Covid-19. Although trying to avoid crowds, in reality there are still places where the sacrificial animals are slaughtered to be a busy spectacle for the public so that the 
density cannot be strictly maintained (European Commission, 2020). This is as stated by Kresna and Ahyar (2020) that the public needs to implement health protocols in an effort to prevent the spread of the Corona virus. Overcrowding of officers while working in the meat and poultry industry is very likely to cause the risk of transmission of SARS-CoV2 considering that very small virus particles occur (Shaw et al., 2020). Physical distancing (keeping a distance) during activities is a pattern of adaptation to new habits in the new normal era (Government of Ireland, 2020; IACP, 2020, Wei et al., 2020; Pradana and Casman, 2020). Physical distancing is one way to minimize the spread of Covid-19, among others, by maintaining a minimum distance of 1 meter between one officer and another.

The results show that $69.23 \%$ of officers implement physical distancing with a minimum distance setting of 1 (one) meter, and the remaining $30.77 \%$ have not been able to implement the above. This is related to the fact that skinning, chopping, handling and packaging of meat are not carried out face to face (76.92\%) while $23.08 \%$ still carry out these activities face to face, which means that social distancing protocols are still being ignored.

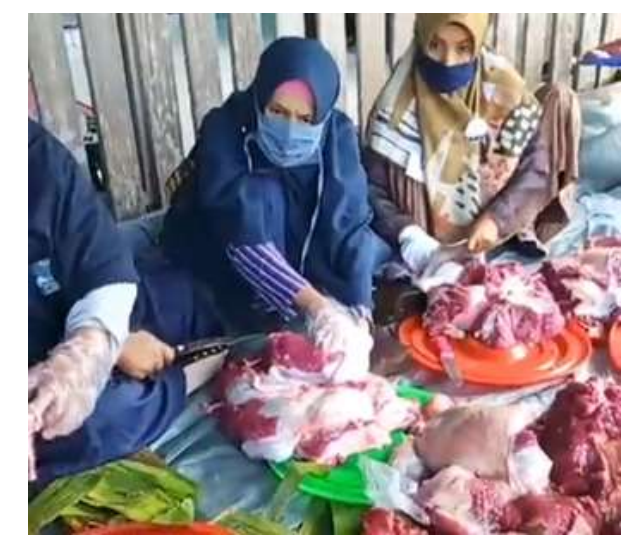

Further research by Dyal et al., (2020) that operationally the distance between one officer and another during work should be 2 (two) meters. This rule refers to the 2020 CDC (Centers for Disease Control and Prevention) which explains that to limit the risk of transmission in the food processing process, one of them is to implement safety procedures to maintain a distance of 2 (two) meters between workers.

Further research by Dyal et al., (2020) that operationally the distance between one officer and another during work should be 2 (two) meters. This rule refers to the 2020 CDC (Centers for Disease Control and Prevention) which explains that to limit the risk of transmission in the food processing process, one of them is to implement safety procedures to maintain a distance of 2 (two) meters between workers .

It is very important for each officer to have their own cutting tools, in order to minimize the spread of Covid-19. A total of $92.31 \%$ of officers brought their own equipment and did not borrow tools, while the remaining $7.69 \%$ did not bring their own tools, or borrowed from other officers. The FDA recommends that all equipment and equipment used by staff should be self-washed, segregated, and not borrowed to minimize the spread of viral infections. 
After the work, officers are expected to maintain cleanliness by washing equipment or spraying disinfectant liquid in accordance with operational procedures to minimize the spread of the virus (Dylah et al. 2020). This can be seen from the results that $100 \%$ of the officers clean the slaughterhouse and the equipment used and dispose of the dirt or waste in the sewage or waste handling facilities.

Furthermore, before returning home and contacting the family, the officers also carried out self-cleaning independently. Thippareddi (2020) stated that the cleaning of all equipment after the operation is complete is divided into several stages. The first is cleaning from dirty materials, then washing with water using soap and other materials that can physically remove dirt, then rinsed again until clean. Although in general this activity does not have an effective impact on the presence of viruses, but the application of cleaning with cleaning agents can make the virus inactive. It was further stated that wet cleaning involves an alkaline solution (alkaline based) as a cleaner to remove protein and fat present, acid based compounds can also remove mineral residues and detergents can remove all dirt and soil present in the soil. surface.

The distribution of Qurban meat as much as $84.62 \%$ was carried out by the committee to the mustahik's house, this was in order to shorten the risk of transmission of the Covid-19 chain of transmission and minimize contact with individual people. However, there are still distributions carried out by the committee not to mustahik, but directly to the surrounding community, which is $15.38 \%$. The tipping point for the spread of Covid-19 could occur at this stage. The distribution of sacrificial animals is one thing that must be considered. This is because Covid-19 can remain present for up to 24 hours and several days on packaging surfaces, such as those from cardboard (for packaging cardboard) and plastic bags, even though humidity and temperature levels are factors that support the virus to develop faster. The use of packaging materials can trigger the risk of transmission of Covid-19 by infected officers. (European Commission, 2020). Viruses that are in the packaging and touched by the skin (held by hands, which then touch the face area), will transfer the virus. Thus, the handling of packaging and distribution to consumers should still follow the Covid-19 health standards regarding sanitation practices, including regularly washing hands or using hand sanitizers after distributing Qurban meat, and consumers immediately replacing their own packaging materials after receiving them. The results of the study at FERN (2020) that in June 2020 approximately 250 packaged meat and 86 plants in the processing process from 46 farmers were confirmed to have Covid-19 cases. This is an example that this pandemic has significantly affected the economy as well as the food sector with risks to worker management.

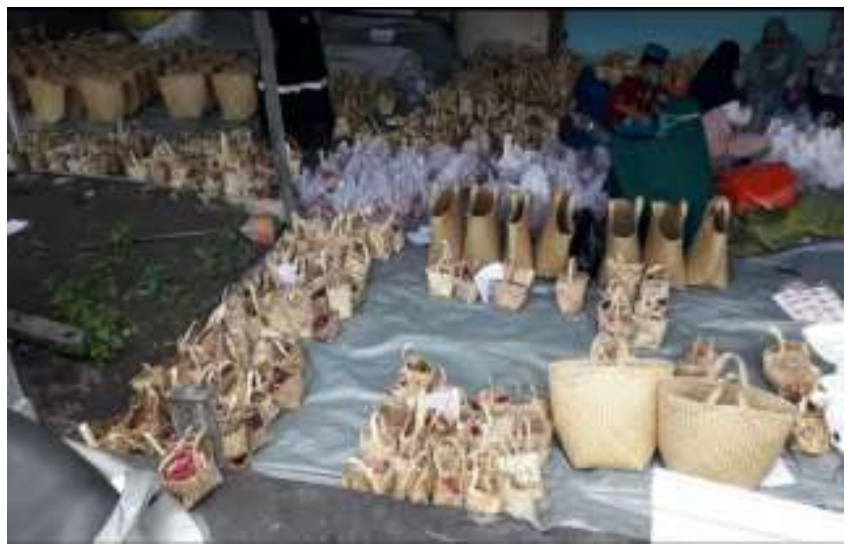


Calculation of the understanding value category of the health protocol for slaughtering sacrificial animals during the New Normal pandemic was carried out using the Guttman Scale. The Guttman scale will provide a firm response, which consists of two alternatives, namely yes and no answers. This will make it easier to see how the reality of the health protocol for slaughtering sacrificial animals is during the New Normal pandemic. The calculation of the score for each question and the ideal percentage of understanding the health protocol for slaughtering sacrificial animals, obtained a value of 92\% of the health protocol for slaughtering sacrificial animals on the Guttman scale, including in the sufficient category. Based on the standards set, the value of $92 \%$ is classified as very good because it is between $76 \%-100 \%$. It can be concluded that the understanding of the health protocol on the slaughter of sacrificial animals during the pandemic in the New Normal era is very good.

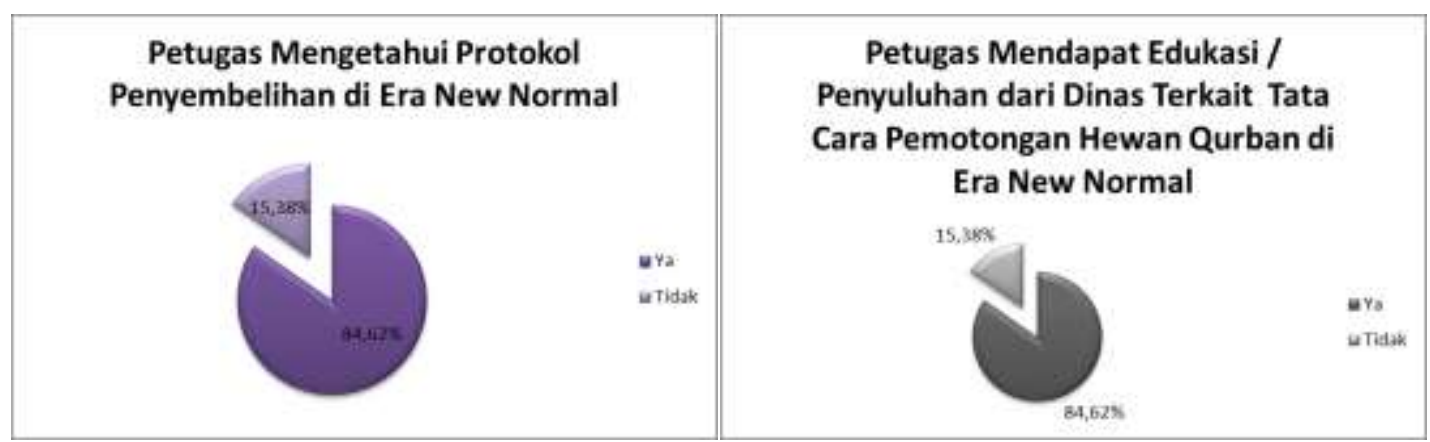

The provision of education, namely $76.92 \%$ there has been education from the officer in charge of Qurban activities, namely educating everyone to avoid or touch the face (including eyes, nose, ears and mouth), It is important for officers to understand health protocols such as preventing touching around the face with hands, preventing contact with large numbers of people (WHO, 2020).

Hygiene control is used to prevent contamination of food (meat) from pathogenic microbes and aims to maintain food contamination from the possibility of the Covid-19 virus. The education and socialization that has been carried out by the service was carried out online via Zoom on July 15, 2020 with the theme "Safe and Parenting Sacrifice in the Covid-19 Pandemic Period". The obstacle faced is that there are still many mosque takmirs who do not participate in the socialization event due to limited knowledge in accessing online media so that information has not been received by the public at large.

The SPPS calculation was carried out using a chia square analysis to see the strong relationship between providing education regarding the health protocol for slaughtering sacrificial animals during the New Normal era pandemic and public understanding of the health protocol for slaughtering sacrificial animals during the New Normal era pandemic. The results of the Chia Square analysis show a significance value of $\mathrm{P}=0.657$ so that based on this value, it shows that there is no relationship between providing education from the service with an understanding of the health protocol for slaughtering sacrificial animals during the New Normal era pandemic. It is suspected that the public received information related to the order of slaughtering Qurban animals in the new normal era, not only from the Department, but also on social media, including through Facebook, Instagram, Whatsapp groups, and television. 


\section{Conclusion}

The results of this study can be concluded that the qurban animal slaughtering officers generally know the health protocol, and their understanding of the qurban animal slaughter protocol during the pandemic is in the very good category. Furthermore, it is expected to be further improved to complete the equipment that supports the health protocol for slaughtering sacrificial animals in the future. Cooperation with relevant agencies to provide education is very necessary in this regard.

\section{References}

Akiyama M.J, A.C. Spaulding, and J.D. Rich. 2020 Flattening the curve for incarcerated populations-Covid-19 in jails and prisons. N Engl J Med. Epub Apr 2,2020. https://dx.doi.org/10.1056/NEJMp2005687

ANR - Associação Nacional de Restaurantes (2020). Especial Coronavírus - 6 abril 2020.Edição $547 \quad-\quad$ Ano $12 . \quad$ https://anrbrasil.org.br/wpcontent/uploads/2020/04/news_547r.pdf

Bai, Y., L. Yao, T. Wei, F. Tian, D. Jin, L. Chen, and M. Wang. 2020. Presumed asymptomatic carrier transmission of COVID-19. In Jama - journal of the American medical association. https://doi.org/10.1001/jama.2020.2565.

Booth, T. F., B. Kournikakis, N. Bastien, J. Ho, D. Kobasa, L. Stadnyk, Y. Li, Y. Spence, M., Paton, B. Henry, B. Mederski, D. White, D.E. Low, A. McGeer, A. Simor, M. Vearncombe, J. Downey, F.B. Jamieson, P. Tang, and F. Plummer. 2005. Detection of airborne Severe Acute Respiratory Syndrome (SARS) coronavirus and environmental contamination in SARS outbreak units. The Journalof Infectious Diseases, 191, 1472-1477. https://doi.org/10.1086/429634

CDC. 2020. Meat and poultry processing workers and employers. Atlanta, GA:US Department of Health and Human Services, CDC; 2020. https://www.cdc.gov/coronavirus/2019ncov/community/organizations/meatpoultry-processing-workers-employers.html

Cai, J., W. Sun, J. Huang, M. Gamber, J. Wu, and G. He. 2020. Indirect virus transmission in cluster of COVID-19 cases, Wenzhou, China, 2020. Emerging Infectious Diseases, 26(6), 1343-1345. https://doi.org/10.3201/EID2606.200412

Ceylan, Z., R. Meral, and T. Cetinkaya. 2020. Relevance of SARS-CoV-2 in food safety and food hygiene: potential preventive measures, suggestions and nanotechnological approaches. VirusDis. (April-June 2020) 31(2):154-160

Chen Y, Q. Liu, and D. Guo 2020. Emerging coronaviruses: genome structure, replication, and pathogenesis. J Med Virol. https://doi.org/10.1002/jmv.25681

Chhikara B.S, B. Rathi, J. Singh, and F.N.U. Poonam. 2020. Corona virus SARS-CoV-2 disease COVID-19: infection, prevention and clinical advances of the prospective chemical drug therapeutics. Chem Biol Let; http://pubs.iscience.in/journal/index.php/cbl/article/view/995.

Chia, P. Y., K. K. Coleman, Y. K. Tan, S. W. X. Ong, M. Gum, S. K Lau, and K. Marimuthu, 2020. Detection of air and surface contamination by SARS-CoV-2 in hospital rooms of infected patients. Nature Communications. https://doi.org/10.1038/s41467-020-16670-2 
Choffnes E.R., D.A. Relman, L.A. Olsen, R. Hutton, and A. Mack. 2012. Improving food safety through a one health approach: orkshop summary. Washington, DC: The National Academic Press.p. 115-30

Cui, J., F. Li, and Z. L. Shi. 2019. Origin and evolution of pathogenic coronaviruses. Nature Reviews Microbiology, 17(3), 181-192. https://doi.org/10.1038/s41579018-0118-9.

Decaro, N., and A. Lorusso. 2020. Novel human coronavirus (SARS-CoV-2): A lesson from animal corona viruses. Veterinary Microbiology Article 108693. https://doi.org/10.1016/j.vetmic.2020.108693.

Dhama K, K. Sharun, R. Tiwari, S. Sircar, S. Bhat, and Y.S. Malik. 2019. Coronavirus Disease 2019: COVID-19. Preprints. 2020; https://doi.org/10.20944/preprints202003.0001.v1.

Dyal, J.W., M.P. Grant and K. Broadwater. 2020. Covid-19 among workers in meat and poultry processing facilities 19 states, April 2020. Morbidity and Mortality Weekly Report, 69 (18): 557-561

European Commision. 2020. Covid-19 and Food Safety, Question and Answer. European Commision Directorate General For Health and Food Safety Crisis Management in Food, Animal and Plants. https://ec.europa.eu/health/home_en

European Food Safety Authority (EFSA). 2020. Coronavirus: no evidence that food is a source or transmission route. https://www.efsa.europa.eu/en/news/coronavirus-noevidence-food-source-or-transmission-route

FERN. 2020. Mapping covid-19 outbreaks in the food system | food and environment reporting network. thefern.org/2020/04/mapping-covid-19-in-meat-and-foodprocessing-plants/.

Government of Ireland. 2020. Return to Work Safely Protocol COVID-19 Specific National Protocol for Employers and Workers. https://dbei.gov.ie/en/Publications/Publication-files/Return-to-Work-SafelyProtocol.pdf.

Gu, J., Han, B., and J. Wang. 2020. COVID-19: Gastrointestinal manifestations and potential fecal-oral transmission. Gastroenterology, 158(6), 1518-1519. https://doi.org/10.1053/j.gastro.2020.02.054.

Irish Association for Conselling and Pyscotherapy (IACP). 2020. IACP COVID-19 Return-to-work Guidelines for Members. https://iacp.ie/Covid19-Return-to-workGuidelines-for-Members\#

Jayusman. 2012. Tinjauan hukum islam terhadap ibadah kurban kolektif. Al-'Adalah Vol $\mathrm{X}(4)$.

Kingsbury, J., and R. Lake. 2020. Potential for foodborne transmission of COVID19:Literature review update. https://www.unitedfresh.co.nz/assets/COVID19/UnitedFresh-Potential-for-Foodborne-Transmission-of-Covid-19Literature-Review-Update-19-May-20.pdf

Kresna, A., dan J. Ahyar. 2020. Pengaruh Physical Distancing dan Social Distancing terhadap

Kesehatan dalam Pendekatan Linguistik. Jurnal SyntaxTransformation, 1(4), 1419.

Martineau A.R, D.A. Jolliffe, R.L. Hooper, L. Greenberg, J.F. Aloia, and P. Bergman 2017. Vitamin D supplementation to prevent acute respiratory tract infections: 
systematic review and meta-analysis of individual participant data. BMJ.. https://doi.org/10.1136/bmj.i6583

Monchatre-Leroy E, F .Boue', J.M. Boucher, C. Renault, F. Moutou, M. Ar Gouilh, and G. Umhang. 2017. Identification of alpha and beta coronavirus in wildlife species in France: bats, rodents, rabbits, and hedgehogs. Viruses.. https://doi.org/10.3390/v9120364.

Muhyiddin. 2020. Covid-19, New Normal dan Perencanaan Pembangunan di Indonesia The Indonesian Journal of Development Planning IV (2), 240-252.

Mukharom, H.A. 2020. Kebijakan Nabi Muhammad SAW menanggapi wabah penyakit menular dan implementasinya dalam konteks menanggunlangi Coronavorus Covid19. Jurnal Sosial \& Budaya Syar-i FSH UIN Syarif Hidayatullah. Jakarta Vol 7 No 3.

Pradana, A. A., dan C. Casman. 2020. Pengaruh Kebijakan Social Distancing pada Wabah COVID-19 terhadap Kelompok Rentan di Indonesia. Jurnal Kebijakan KesehatanIndonesia: JKKI, 9(2), 61-67

Pradesh U, P.D.D. Upadhayay, and P.C. Vigyan. 2014. Coronavirus infection in equines: a review. Asian J Anim Vet Adv.. https://doi.org/10.3923/ajava.2014/164.176.

Randazzo, W., P . Truchado, E. Cuevas-Ferrando, Simon, A. Allende, and G.Sanchez, 2020. SARS-CoV-2 RNA in wastewater anticipated COVID-19 occurrence in a low prevalence area. Water Research. , Article 115942. https://doi.org/10.1016/j.watres.2020.115942

Rodriguez-Morales AJ, Bonilla-Aldana DK, Tiwari R, Sah R,Rabaan AA, Dhama K. (2020). COVID-19, an emerging coronavirus infection: current scenario and recent developments: an overview.J Pure Appl Microbiol. 14:6150

Sabiq, S. (1983). Fiqih Al Sunnah. Bayrut : Dar Al-Fikr.

Shanker, D., \& Mulvany, L. (2020). Threat of sick workers at U.S. meat plants forces policy changes Bloomberg: Business. Retrieved from. https://www.bloomberg.com/news/articles/2020-03-20/threat-of-sick-workers-atu-s-meat-plants-forces-policy-changes

Shaw KA, Szablewski CM, Kellner S, Kornegay L, Bair P, Brennan S, et al. Psittacosis outbreak among workers at chicken slaughter plants, Virginia and Georgia, USA, 2018. Emerg Infect Dis 2019;25:21435.https://dx.doi.org/10.3201/eid2511.190703

Syafii, A. (2019). Tiga Miliar Muslim Tahun 2060: Berita Gembira atau Bencana?. https://republika.co.id/berita/q03z7x440/tiga-miliar-muslim-tahun-2060-beritagembira-atau-bencana.

Su, S., Wong, G., Shi, W., Liu, J., Lai, A. C. K., Zhou, J., Liu, W., Bi, Y., \& Gao, G. F.(2016). Epidemiology, genetic recombination, and pathogenesis of coronaviruses.Trends in Microbiology, 24(6), 490-502. https://doi.org/10.1016/j.tim.2016.03.003.

Tribunnewsmaker. (2020). DKI Jakarta Bertambah 1.380 Kasus Update Corona Nasional. https://newsmaker.tribunnews.com/2020/09/14/dki-jakarta-bertambah1380-kasus-update-corona-nasional-senin-14-september-2020-total-218382. (diakses 14 September 2020)

Van Doremalen, N., Bushmaker, T., \& Munster, V. J. (2013). Stability of Middle East respiratory syndrome coronavirus (MERS-CoV) under different environmental 
conditions. Euro Surveillance, 18(38), 20590. https://doi.org/10.2807/15607917.ES2013.18.38.20590.

Velebit B, Djordjevic V, Milojevic L, Babic M, Grkovic N,Jankovic V. (2019). The common foodborne viruses: a review.Earth Env Sci. Publishing. https://doi.org/10.1088/1755-1315/333/1/012110

Wei WE, Li Z, Chiew CJ, Yong SE, Toh MP, Lee VJ. Presymptomatic transmission of SARS-CoV-2 - Singapore, January 23-March 16, 2020.MMWR Morb Mortal Wkly Rep 2020;69:411-5. http://dx.doi.org/10.15585/mmwr.mm6914e1

World Health Organization (WHO). (2020). Technical interim guidance for novel coronavirus. https://www.who.int/health-topics/coronavirus. Accessed 29 Jan 2020 .

World Health Organization and Food and Agriculture Organization of the United Nations. (2020). COVID-19 and food safety: guidance for food businesses. WHO/2019nCoV/Food_Safety/2020.1. Accessed 25 May 2020.

$\mathrm{Wu}$ Y. (2020). A multiscale and comparative model for receptor binding of 2019 novel coronavirus and the implication of its life cycle in host cells. BioRxiv. https://doi.org/10.1101/2020.02.20.958272.

Yuan J, Lu Y, Cao X, Cui H. (2020)Regulating wildlife conservation and food safety to prevent human exposure to novel virus. Ecosyst Health Sust.. https://doi.org/10.1080/20964129.2020.1741325. 